\title{
Role of cellular factors in the replication of human retroviruses: recent insights
}

\author{
Kuan-Teh Jeang \\ From Frontiers of Retrovirology 2011 \\ Amsterdam, The Netherlands. 3-5 October 2011
}

We and others have described the use of genome-wide screenings for cellular factors that contribute to HIV-1 replication $[1,2]$. One aspect of the HIV-1 life cycle important to viral replication is the post-transcriptional regulation of HIV-1 gene expression. In HIV-1 biology, a key step in gene expression is the post-transcriptional export of intron-containing viral RNAs which bypass the normal mechanism(s) that retain cellular intron-containing RNAs in the nucleus. Specific signals on the viral RNAs, such as instability sequences (INS) and Rev responsive element (RRE), are binding sites for viral and cellular factors that serve to regulate RNA-export. The HIV-1 encoded viral Rev protein binds to the RRE found on unspliced and incompletely spliced viral RNAs. Binding by Rev directs the export of these RNAs from the nucleus to the cytoplasm. Previously, Rev cofactors have been found to include cellular factors such as CRM1, DDX3, PIMT and Matrin3 [3,4]. I will discuss these and other cellular factors that influence HIV-1 replication.

Published: 3 October 2011

\footnotetext{
References

1. Yeung ML, Houzet L, Yedavalli VS, Jeang KT: A Genome-wide Short Hairpin RNA Screening of Jurkat T-cells for Human Proteins Contributing to Productive HIV-1 Replication. J Biol Chem 2009, 284:19463-73.

2. Kok KH, Lei T, Jin DY: siRNA and shRNA screens advance key understanding of host factors required for HIV-1 replication. Retrovirology 2009, 6:78.

3. Yedavalli VSRK, Jeang KT: Matrin 3 is a co-factor for HIV-1 Rev in regulating post-transcriptional viral gene expression. Retrovirology 2011, 8:61.

4. Kula A, Guerra J, Knezevich A, Kleva D, Myers MP, Marcello A: Characterization of the HIV-1 RNA associated proteome identifies Matrin 3 as a nuclear cofactor of Rev function. Retrovirology 2011, 8:60.
}

National Institutes of Health, Bethesda, MD 20892, USA
doi:10.1186/1742-4690-8-S2-O21

Cite this article as: Jeang: Role of cellular factors in the replication of human retroviruses: recent insights. Retrovirology 2011 8(Suppl 2):O21.
Submit your next manuscript to BioMed Central and take full advantage of:

- Convenient online submission

- Thorough peer review

- No space constraints or color figure charges

- Immediate publication on acceptance

- Inclusion in PubMed, CAS, Scopus and Google Scholar

- Research which is freely available for redistribution

\section{() Biomed Central}

\section{Biomed Central}

